\title{
Accumulation of dietary glycotoxins in the reproductive system of normal female rats
}

\author{
Evanthia Diamanti-Kandarakis • Christina Piperi • \\ Penelope Korkolopoulou • Eleni Kandaraki • \\ Georgia Levidou • Apostolos Papalois • \\ Efstratios Patsouris - Athanasios G. Papavassiliou
}

Received: 21 May 2007 /Revised: 10 July 2007 / Accepted: 13 July 2007 / Published online: 11 August 2007

(C) Springer-Verlag 2007

\begin{abstract}
The aim of the present study was to investigate whether dietary advanced glycation end-products (AGEs) can be detected in the ovarian tissue of normal female rats and whether they can affect their metabolic or hormonal profile. Sixty normal rats (20 animals in each group) were randomly assigned to regular diet, either high (H-AGE) or low (L-AGE) in AGE content for 6 months. H-AGE rats demonstrated higher levels of fasting glucose $(P<0.001)$, insulin $(P<0.069)$, and serum AGEs $(P<0.001)$ than control and L-AGE rats. Additionally, the H-AGE group showed increased AGE localization in the theca interna cells of the ovarian tissue compared to control/L-AGE rats $(P=0.003)$. Furthermore, increased receptor for AGE (RAGE) staining was also observed in granulosa cells compared to control/L-AGE samples $(P=0.038)$. In the HAGE group, plasma testosterone was higher than in control rats $(P<0.001)$ and in the L-AGE group $(P<0.001)$. However, H-AGE rats did not exhibit higher body weight
\end{abstract}

\footnotetext{
E. Diamanti-Kandarakis

First Department of Internal Medicine, Endocrine section,

Medical School, University of Athens,

Athens, Greece

C. Piperi $\cdot$ E. Kandaraki $\cdot$ A. G. Papavassiliou $(\triangle)$

Department of Biological Chemistry, Medical School,

University of Athens,

75, M. Asias Street,

11527 Athens, Greece

e-mail: papavas@med.uoa.gr
}

P. Korkolopoulou $\cdot$ G. Levidou $\cdot$ E. Patsouris

Department of Pathology, Medical School, University of Athens, Athens, Greece

\section{A. Papalois}

ELPEN S.A, Experimental Research Center,

Athens, Greece

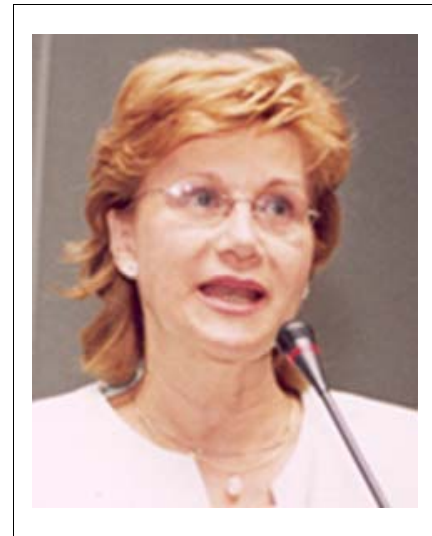

EVANTHIA DiAmanti-Kandarakis received her M.D. from Athens Medical School, Greece and her $\mathrm{Ph} . \mathrm{D}$. in experimental endocrinology on the effects of androgens in female hypophysectomised rats from the same University. She is presently Associate Professor of Endocrinology and Metabolism and Chief of the Endocrine section at the 1st Department of Medicine, Athens University. Her research interests include molecular and environmental studies on insulin action on PCOS.

compared with normal $(P=0.118)$ and L-AGE-fed rats $(P=$ 0.35 ). These results demonstrate for the first time that administration of high AGE diet in female rats for a prolonged period is associated with increased deposition of AGEs in the theca cells and of RAGE in the granulosa and theca interna cells of the ovarian tissue compared with the corresponding ovarian compartments of the control and 
L-AGE-fed animals. The metabolic alterations in conjuction with the increased deposition in ovarian tissues of dietary glycotoxins and elevated levels of testosterone in $\mathrm{H}-$ AGE-fed animals compared to the controls suggest an impact of environmental factors on ovarian tissue and these findings need further exploration.

Keywords AGEs · Insulin · Ovaries · RAGE - Testosterone

\section{Introduction}

In the modern world, it has been demonstrated that populations adopting a Western lifestyle and diet independently of their genetic background exhibit alterations in their metabolic profile. However, the impact of Western diets on the reproductive system in humans and animals has started to attract major scientific interest.

Advanced glycation end-products (AGEs) are highly reactive molecules, formed by nonenzymatic glycation of proteins, lipids, and nucleic acids, which may induce structural and vascular changes $[1,2]$. The mechanisms by which AGE leads to these injuries in multicellular structures remain largely unknown; however, the formation of insoluble cross-links, the induction of oxidative stress, and cell activation play a significant role. Interaction of AGE with specific cellular receptors (RAGE) leads to cell activation, release of cytokines, and growth factors, which contribute to abnormal cell/ matrix proliferation, such as seen in diabetic renal lesions and atheromas [3-5]. AGEmodified proteins are continuously formed in the body from the reaction of reducing sugars, but they can also be produced from exogenous sources during contemporary methods of cooking (precooked fast food meals heated in high temperatures) [6-9]. There is evidence that AGE absorption from food is associated with the protein and fat ingredients [9]. Recent reports have confirmed oral absorption and tissue incorporation of end-products originating from mixed foods [10]. Human studies confirmed that about $10 \%$ of exogenous AGEs are absorbed and correlate with circulating and tissue AGEs levels, exceeding their endogenous production [11]. Data in humans and experimental animals favor that exogenous food-ingested AGEs result in elevated serum levels and increased tissue deposition [12, 13]. Specifically, ingestion of a meal rich in AGEs has led to increased serum levels of AGEs in diabetic patients, which were compared with controls, and tissue deposition was enhanced when the AGE meals were rich in fat [11].

Furthermore, normal mice fed high-fat diets rich in AGE content for 6 months displayed markedly impaired glucose and insulin responses during glucose tolerance tests and altered pancreatic islet structure and function compared with those of control mice fed with a low-AGEcontent diet [14].

While the mechanisms linking AGEs and the related deleterious metabolic effects are likely to be complex, the evidence indicates that lowering AGE content in fatty foods might be a mode of intervention to control metabolic sequelae. Dietary AGE restriction has been shown to result in significant reduction in circulating AGE levels and disease progression in animal models of atherosclerosis [13] and diabetes [15] and in diabetic patients with or without renal impairment [16]. These findings suggest that dietary AGEs represent a significant source of circulating and tissue-deposed AGEs, possibly manifesting similar pathogenic properties to their endogenous counterparts, and they may further constitute a chronic environmental risk factor for tissue injury.

Recently, AGEs levels were found to be elevated in serum of young normoglycemic women with polycystic ovary syndrome (PCOS) [17]. In addition, increased immunostaining of AGE and RAGE was observed in the different compartments of the ovarian tissue in polycystic ovaries [18]. Furthermore, young women with PCOS demonstrated increased serum levels of AGEs after receiving a high-AGE diet [19]. The source of these glycosylated end-products in normoglycemic women with PCOS has not been determined and could be either endogenous or exogenous.

In the present study, the deposition of food glycotoxins on the ovarian tissue of normal female rats is investigated for the first time. It was postulated that female rats subjected to long-term feeding on high- or low-AGE diet content could be detected on the ovarian tissue. Furthermore, measurements of plasma testosterone were performed in parallel with estimation of glucose and insulin levels.

\section{Materials and methods}

Animals and diets

Wistar rats (60 animals total; female, 12 weeks old) were housed at ELPEN S.A, Experimental Research Center, Athens, Greece. Animal care and experimental procedures conformed with the "Guide for the Care and Use of Laboratory Animals" (Department of Health, Education and Welfare, Athens, Greece) and were approved by the Institutional Animal Care and Use Committee.

The diets used were derived from a single standard rat chow (AIN-93G) purchased from Bioserve (Frenchtown, NJ), consisting of $18 \%$ protein, $58 \%$ carbohydrate, $7.5 \%$ fat, and $3.73 \mathrm{kcal} / \mathrm{g}$. Regular AIN-93G chow is normally prepared by heating at $100^{\circ} \mathrm{C}$ for $20 \mathrm{~s}$ and at $125^{\circ} \mathrm{C}$ for $30 \mathrm{~min}[20,21]$.

Analysis of the AGE content of rat chow after heating was performed in collaboration with Dr. Henle's Laborato- 
ry, Institute of Food Chemistry, Technische Universität Dresden, Dresden, Germany. This preparation contained $76.0 \pm 15.3 \mathrm{mg}$ carboxymethyllysine (CML)/100 g sample (or $436.9 \pm 88.1 \mathrm{mg} \mathrm{CML} / 100 \mathrm{~g}$ protein), $205.32 \pm 22.25 \mathrm{mg}$ fructoselysine/100 $\mathrm{g}$ sample (or $1,179.98 \pm 127.90 \mathrm{mg}$ fructoselysine $/ 100 \mathrm{~g}$ protein), and $52.68 \pm 5.71 \mathrm{mg}$ furosine $/ 100 \mathrm{~g}$ sample (or $302.78 \pm 32.82 \mathrm{mg}$ furosine/100 $\mathrm{g}$ protein) and was used as a high-in-AGE diet (H-AGE). The same rodent mix was also prepared by heating at $100^{\circ} \mathrm{C}$ for $20 \mathrm{~s}$ only; this preparation was of equivalent macro- and micronutrient and energy content but contained $1.3 \pm 0.4 \mathrm{mg}$ $\mathrm{CML} / 100 \mathrm{~g}$ sample (or $7.7 \pm 2.2 \mathrm{mg} \mathrm{CML} / 100 \mathrm{~g}$ protein), $104.58 \pm 3.08 \mathrm{mg}$ fructoselysine $/ 100 \mathrm{~g}$ sample (or $601.01 \pm$ $17.7 \mathrm{mg}$ fructoselysine $/ 100 \mathrm{~g}$ protein), and $26.83 \pm 0.79 \mathrm{mg}$ furosine $/ 100 \mathrm{~g}$ sample (or $154.22 \pm 4.54 \mathrm{mg}$ furosine $/ 100 \mathrm{~g}$ protein) and was considered as a low-in-AGE diet (L-AGE) (Table 1).

Analysis for total nitrogen and protein content was carried out according to Kjeldahl's method. For calculation of the protein content (nitrogen content multiplied with a specific Protein factor), the factor $F=6.25$ for unknown proteins was used. Measurements of CML were carried out via gas chromatography-mass spectroscopy after derivatization to the trifluor-acetic acid-methylesters. $N$-Carboxymethylornithine served as an internal standard. CML was

Table 1 Characteristics of dietary formulas with H-AGE and L-AGE glycotoxin content

\begin{tabular}{lll}
\hline & H-AGE & L-AGE \\
\hline Assays & & \\
CML (mg/100 g protein) & $436.9 \pm 88.1$ & $7.7 \pm 2.2$ \\
Fructoselysine (mg/100 g protein) & $1179.98 \pm 127.90$ & $601.01 \pm 17.7$ \\
Furosine (mg/100 g protein) & $302.78 \pm 32.82$ & $154.22 \pm 4.54$ \\
Nutrients (\%) & & \\
Protein & 18.4 & 18.4 \\
Lipids & 7.2 & 7.2 \\
Carbohydrate & 58.6 & 58.6 \\
Other (fiber, moisture) & 15.8 & 15.8 \\
Total calories (kcal/g) & 3.9 & 3.9 \\
Micronutrients (kg) & & \\
Biotin & $0.2 \mathrm{mg}$ & $0.2 \mathrm{mg}$ \\
Folate & $2 \mathrm{mg}$ & $2 \mathrm{mg}$ \\
Niacin & $30 \mathrm{mg}$ & $30 \mathrm{mg}$ \\
Pyridoxine (B6) & $6 \mathrm{mg}$ & $6 \mathrm{mg}$ \\
Riboflavin & $6 \mathrm{mg}$ & $6 \mathrm{mg}$ \\
Thiamin & $5 \mathrm{mg}$ & $5 \mathrm{mg}$ \\
Vitamin A & $4,000 \mathrm{IU}$ & $4,000 \mathrm{IU}$ \\
Vitamin B-12 & $25 \mu \mathrm{gg}$ & $25 \mu \mathrm{g}$ \\
Vitamin E & $75 \mathrm{IU}$ & $75 \mathrm{IU}$ \\
Vitamin D3 & $1,000 \mathrm{IU}$ & $1,000 \mathrm{IU}$ \\
\hline
\end{tabular}

Nutrients and micronutrients content were obtained from the study of Lin et al. [21] released from the protein by acid hydrolysis with $6 \mathrm{~N} \mathrm{HCl}$ at $110^{\circ} \mathrm{C}$ for $23 \mathrm{~h}$.

Calculation of fructoselysine was carried out according to Krause et al. [22] by multiplying the molar amount of furosine with a conversion factor of 3.1. Measurements of furosine were carried out via high-performance liquid chromatography with UV detection at $280 \mathrm{~nm}$ according to Resmini et al. [23] after acid hydrolysis with $6 \mathrm{~N} \mathrm{HCl}$ at $110^{\circ} \mathrm{C}$ for $23 \mathrm{~h}$. Results related to $100 \mathrm{~g}$ protein are based on a protein content of $17.4 \%$.

Control rats were given a standard rat chow containing $23.4 \%$ protein, $4.5 \%$ fat, $5.3 \%$ crude fiber, $6.9 \%$ ash, $0.95 \%$ calcium, and $0.67 \%$ phosphorus.

\section{Experimental design}

At 12 weeks of age, animals (20 animals in each group) were randomly assigned to the diets for 6 months. Rats were given pelleted food and water ad libitum in a specific pathogen-free environment at the animal laboratory. Body weight, serum glucose, and insulin and testosterone concentrations were monitored every 3 months. At the end of the 6 months, rats were killed for blood collection and ovarian tissue retrieval.

Immunohistochemistry

Paraffin-embedded sections of formalin-fixed ovarian tissue were deparaffinized by xylene and dehydrated in graded ethanol. Sections were treated in 3\% hydrogen peroxide in phosphate-buffered saline (PBS) for $15 \mathrm{~min}$ and then rinsed in PBS. To increase the immunoreactivity of AGEs, the sections were placed in $500 \mathrm{ml}$ of $0.01 \mathrm{M}$ citric acidbuffered solution $(\mathrm{pH} 7.0)$ and microwaved at $500 \mathrm{~W}$ for $5 \mathrm{~min}$. After thorough washing, the sections were incubated with normal rabbit serum for $20 \mathrm{~min}$ at room temperature to avoid nonspecific binding of the antibodies. The sections were then incubated overnight at $4^{\circ} \mathrm{C}$ with the anti-AGE monoclonal antibody, $6 \mathrm{D} 12(0.25 \mathrm{mg} / \mathrm{ml}$ stock, dilution 1:50; Research Diagnostics, Concord, MA) or goat monoclonal anti-RAGE antibody $(0.25 \mathrm{ml}$, dilution 1:400; RDIRAGEabG, Research Diagnostics) in PBS containing 1\% bovine serum albumin. Immunoreactivity was detected by the streptavidin-biotin-peroxidase method according to the manufacturer's protocol. The final reaction product was visualized with 3,3'-diaminobenzidine tetrahydrochloride (LSAB detection kit; Dako, Carpinteria, CA). Lung tissue sections from diabetic rats were used as positive controls for AGE and RAGE antibodies. Negative controls (e.g., ovarian tissue in which the primary antibody was substituted with nonimmune mouse or goat serum) were also stained in each run. Fourteen sections of control and LAGE rat ovaries were evaluated along with 19 sections of 
H-AGE rat ovaries. The percentage of positive cells was estimated using light microscopy. The evaluation of the immunostained slides was performed blindly and independently by two pathologists. AGE and RAGE expression were categorized in four levels according to the percentage of positive cells, as follows: minimum (staining $1-10 \%$ of cells), low (staining $11-30 \%$ of cells), moderate $(31-60 \%$ of cells), and extensive (more than $60 \%$ of cells) immunostaining. The staining intensity was also assessed in four levels: 1 , very weak; 2 , weak; 3 , moderate; and 4 , strong.

\section{Assays}

Serum fasting glucose concentrations $(\mathrm{mg} / \mathrm{dl})$ were measured with the glucose oxidase technique (Linear Diagnostics, Spain). Serum insulin levels $(\mu \mathrm{IU} / \mathrm{ml})$ were evaluated with an enzyme immunoassay (Insulin enzyme-linked immunosorbent assay [ELISA] kit, Mercodia AB, Uppsala, Sweden). Serum testosterone levels $(\mathrm{ng} / \mathrm{ml})$ were estimated using the commercially available immunoassay kit from IBL Immunoassays, Germany.

Serum AGE levels $(\mathrm{U} / \mathrm{ml})$ were measured by AGEspecific competitive ELISA as described previously [17].

\section{Statistical analysis}

All data are given as mean $\pm \mathrm{SE}$. Differences of means were analyzed by analysis of variance, which was followed by post-hoc analysis using Bonferroni correction for multiple comparisons. When comparing the differences in the AGE and RAGE expression levels, animals receiving the normal diet were assigned in the same group with those receiving L-AGE diet because they displayed a similar distribution regarding AGE and RAGE staining. The respective differences in the AGE and RAGE expression levels between this group (controls/L-AGE) and the group of animals receiving $\mathrm{H}$-AGE diet were tested employing logistic regression analysis for case-control studies (using the variable denoting which animal is the H-AGE fed and which one the L-AGE/control as a dependent variable) as well as Fisher's exact test. Statistically significant difference was defined as a $P$ value less than 0.05 . All reported $P$ values are based on two-sided tests. All data analyses were performed using the SPSS 14.0 for windows.

\section{Results}

Effect of dietary glycotoxins in ovarian weights, in serum AGEs, and glucose levels

Body weights (grams) were similar before the initiation of the experiment and did not show a statistically significant change after the experiment within the control, H-AGE, and L-AGE-fed rats $(P=$ not significant, Table 2$)$. However, post-treatment weight in the H-AGE group was significantly lower than in the L-AGE group ( $P=0.015$, Table 2$)$.

Ovarian tissue weight (grams) was increased in H-AGE rats compared to controls $(P<0.001)$ as well as between $\mathrm{H}$ AGE rats and L-AGE $(P=0.005)$.

Significant correlations were obtained between body weight and ovarian tissue weight after the 6-month treatment period $(r=-0.422, P=0.018)$.

Fasting blood glucose $(\mathrm{mg} / \mathrm{dl})$ was higher in H-AGE rats compared to controls $(P<0.001)$ as well as compared to L-AGE rats $(P<0.001)$.

Fasting glucose levels were negatively correlated with body weights $(r=-0.386, P=0.032)$ after the 6-month treatment period.

Fasting serum AGE levels $(\mathrm{U} / \mathrm{ml})$ were significantly higher in the H-AGE-fed compared with the L-AGE-fed rats $(P=0.001$; Table 2$)$ as well as with controls $(P<0.001)$.

AGE levels correlated negatively with body weights $(r=-0.557, P=0.001)$ and positively with ovarian tissue weight $(r=0.433, P=0.012)$, fasting glucose $(r=0.374$, $P=0.027)$, and serum testosterone levels $(r=0.463, P=$ 0.035 ) after the 6-month treatment period.

Table 2 Anthropometric, metabolic and hormonal parameters of the three study groups

\begin{tabular}{lllllll}
\hline Variable & $\begin{array}{l}\text { Control } \\
(N=20)\end{array}$ & $\begin{array}{l}\text { L-AGE } \\
(N=20)\end{array}$ & $\begin{array}{l}\text { H-AGE } \\
(N=20)\end{array}$ & $\begin{array}{l}P \text { value, control } \\
\text { vs L-AGE }\end{array}$ & $\begin{array}{l}P \text { value, control } \\
\text { vs H-AGE }\end{array}$ \\
\hline Rat weight $(\mathrm{g})$ & $242.5 \pm 14.24$ & $262.14 \pm 10.79$ & $215.27 \pm 8.4$ & 0.350 & 0.118 & 0.015 \\
Ovarian weight $(\mathrm{g})$ & $0.53 \pm 0.1$ & $0.577 \pm 0.1$ & $1.12 \pm 0.079$ & 0.77 & $<0.001$ & 0.005 \\
Fasting glucose $(\mathrm{mg} / \mathrm{dl})$ & $109.87 \pm 6.64$ & $87.6 \pm 4.42$ & $149.5 \pm 6.06$ & 0.015 & $<0.001$ & $<0.001$ \\
Fasting insulin $(\mu \mathrm{IU} / \mathrm{ml})$ & $0.418 \pm 0.189$ & $0.36 \pm 0.167$ & $0.78 \pm 0.094$ & 0.822 & 0.069 & $<03$ \\
Testosterone $(\mathrm{ng} / \mathrm{ml})$ & $0.06 \pm 0.01$ & $0.054 \pm 0.02$ & $0.139 \pm 0.009$ & 0.754 & $<0.001$ & $<0.001$ \\
Serum AGEs $(\mathrm{U} / \mathrm{ml})$ & $5.06 \pm 0.06$ & $4.35 \pm 0.3$ & $9.88 \pm 1.07$ & 0.055 & $<0.001$ & 0.001 \\
\hline
\end{tabular}

Data are given as means \pm SEM, $P<0.05$ statistically significant. Post-hoc tests were used to derive the respective $P$ values because of the fact that all the overall tests were proved to be statistically significant. 
Effect of dietary glycotoxins in insulin and testosterone levels

H-AGE rats demonstrated higher levels of fasting insulin $(\mu \mathrm{IU} / \mathrm{ml})$ than control $(P=0.069)$ and L-AGE rats $(P=0.03)$.

In addition, the H-AGE group presented higher plasma testosterone levels $(\mathrm{ng} / \mathrm{ml})$ compared to control rats $(P<$ $0.001)$ and to the L-AGE group $(P<0.001)$.

Testosterone levels correlated positively with ovarian tissue weight $(r=0.615, P=0.005)$, fasting glucose levels $(r=0.641, P=0.002)$, and AGE levels $(r=0.463, P=0.035)$ after the 6-month treatment period.

Immunohistochemical localization of AGEs in ovarian tissue of control, L-AGE and H-AGE-fed rats

Control and L-AGE ovarian tissue samples presented a similar distribution regarding AGE staining and, as men- tioned earlier, were considered as one group. Statistical analysis was therefore performed in two groups namely, control/L-AGE $(N=14)$ and H-AGE $(N=19)$. The results of both logistic regression analysis and Fisher's exact test for the comparison of the two groups are reported in Table 3. The two methods, as expected, yielded similar results.

AGE expression was detected in all cases of control/LAGE (14/14) and H-AGE (19/19) ovarian tissue, but it was more extensive in the ovaries of H-AGE-fed rats compared to controls/L-AGE (logistic regression analysis, $P=0.003$ ). In addition, $\mathrm{H}-\mathrm{AGE}$ rats ovaries displayed a higher intensity of AGE staining compared to control/L-AGE (logistic regression analysis, $P=0.007)$.

AGE immunoreactivity was detected in granulosa, theca, and luteinized cells as well as in the ovarian stroma. However, the H-AGE group presented higher AGE expression levels in the theca interna cells when compared to controls (logistic regression analysis, $P=0.003$, Fig. 1),

Table 3 Immunohistochemistry data of AGE and RAGE staining in ovarian tissue and uterine tubes of control, L-AGE $(N=14)$, and H-AGE rats $(N=19)$

\begin{tabular}{|c|c|c|c|c|c|c|c|c|c|}
\hline \multicolumn{5}{|l|}{ AGE } & \multicolumn{5}{|l|}{ RAGE } \\
\hline & $\begin{array}{l}\text { Control+ } \\
\text { L-AGE } \\
\text { (number } \\
\text { of cases) }\end{array}$ & $\begin{array}{l}\text { H-AGE } \\
\text { (number } \\
\text { of cases) }\end{array}$ & $\begin{array}{l}P \text { value, } \\
\text { logistic } \\
\text { regression } \\
\text { analysis }\end{array}$ & $\begin{array}{l}P \text { value, } \\
\text { Fisher's } \\
\text { exact test }\end{array}$ & & $\begin{array}{l}\text { Control + } \\
\text { L-AGE } \\
\text { (\# of } \\
\text { cases) }\end{array}$ & $\begin{array}{l}\text { H-AGE } \\
\text { (\# of } \\
\text { cases) }\end{array}$ & $\begin{array}{l}\mathrm{P} \text { value } \\
\text { Logistic } \\
\text { regression } \\
\text { analysis }\end{array}$ & $\begin{array}{l}P \text { value } \\
\text { Fisher's } \\
\text { exact test }\end{array}$ \\
\hline Expression & & & $0.003^{*}$ & $0.001 *$ & Expression & & & $0.042 *$ & $0.042 *$ \\
\hline Minimum & 6 & 0 & & & Minimum/Low & 2 & 0 & & \\
\hline Low & 6 & 5 & & & Moderate & 4 & 1 & & \\
\hline Moderate & 2 & 8 & & & Extensive & 8 & 17 & & \\
\hline Extensive & 0 & 6 & & & & & & & \\
\hline Intensity & & & $0.007 *$ & $0.007 *$ & Intensity & & & $0.010^{*}$ & $0.018^{*}$ \\
\hline Very weak & 5 & 1 & & & Very Weak/Weak & 2 & 0 & & \\
\hline Weak & 8 & 7 & & & Moderate & 7 & 3 & & \\
\hline Moderate & 1 & 10 & & & Strong & 5 & 15 & & \\
\hline Strong & 0 & 1 & & & & & & & \\
\hline Granulosa cells & & & 0.292 & 0.424 & Granulosa cells & & & $0.038^{*}$ & $0.034 *$ \\
\hline No & 1 & 0 & & & Low expression & 4 & 1 & & \\
\hline Yes & 13 & 19 & & & High expression & 5 & 16 & & \\
\hline Theca cells & & & $0.003^{*}$ & $0.001 *$ & Theca cells & & & 0.052 & $0.047^{*}$ \\
\hline No & 12 & 4 & & & Low expression & 12 & 4 & & \\
\hline Yes & 2 & 12 & & & High expression & 2 & 12 & & \\
\hline Luteinizing cells & & & 0.386 & $-{ }^{\mathrm{a}}$ & Luteinizing cells & & & 0.481 & $-^{\mathrm{a}}$ \\
\hline No & 0 & 0 & & & Low expression & 0 & 0 & & \\
\hline Yes & 14 & 19 & & & High expression & 14 & 18 & & \\
\hline Stroma cells & & & 0.277 & 0.183 & Stroma cells & & & 0.706 & 0.492 \\
\hline No & 2 & 0 & & & Low expression & 0 & 2 & & \\
\hline Yes & 12 & 18 & & & High expression & 13 & 15 & & \\
\hline Uterine tubes & & & 0.313 & 0.44 & Uterine tubes & & & 0.435 & $-^{\mathrm{a}}$ \\
\hline No & 7 & 7 & & & No & 0 & 0 & & \\
\hline Yes & 4 & 9 & & & Yes & 11 & 15 & & \\
\hline
\end{tabular}

Results of logistic regression analysis and Fisher's exact test

$* P<0.05$ statistically significant

${ }^{\mathrm{a}}$ Not applicable 
a

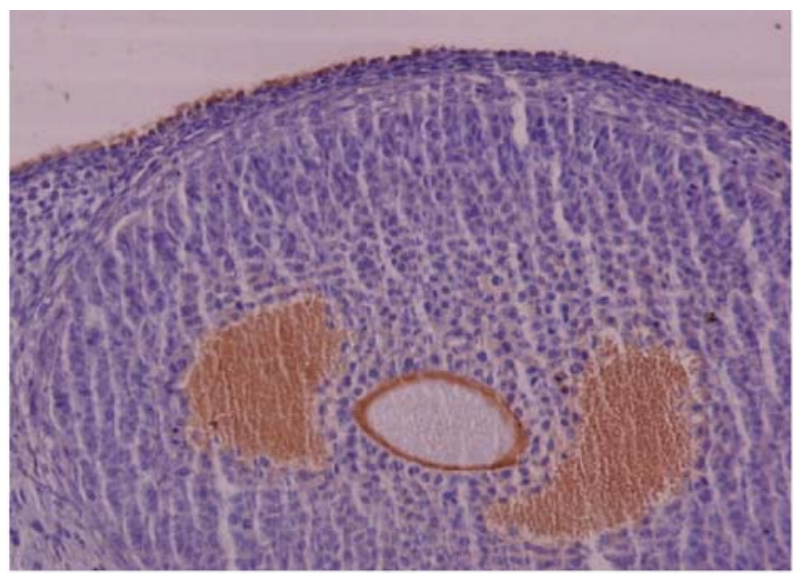

b

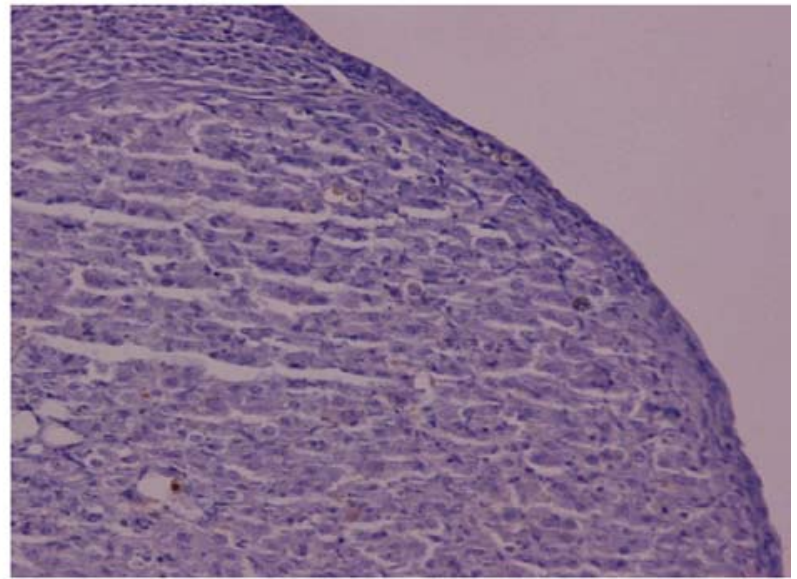

C

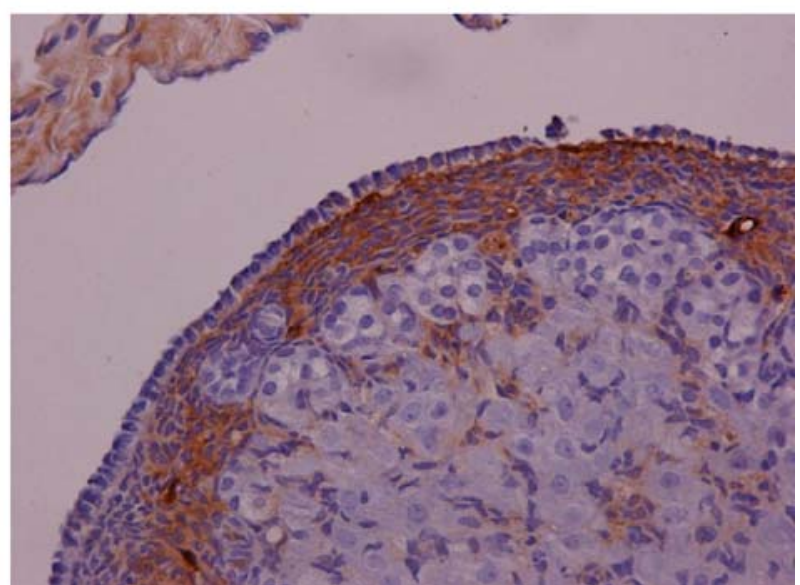

Fig. 1 Immunohistochemical localization of AGE expression in control (a, 100× magnification), L-AGE-fed rat ovary (b, 100× magnification), and H-AGE-fed rat ovary (c, 200× magnification). AGE staining is observed in follicular cell layers and stroma cells; however, AGE staining is stronger in theca interna cells of H-AGE-fed rats compared to control and L-AGE

whereas the respective differences for the granulosa cell layer and luteinizing cells did not achieve statistical significance (logistic regression analysis, $P=0.292$ and $P=$ 0.277 , respectively). Furthermore, there was no difference in the AGE stroma deposition between H-AGE and control/ L-AGE samples (logistic regression analysis, $P=0.386$ ).
AGE staining was also observed in uterine tubes of both H-AGE and control/L-AGE animals, displaying a similar pattern and extension of staining in both groups (logistic regression analysis, $P=0.313$ ).
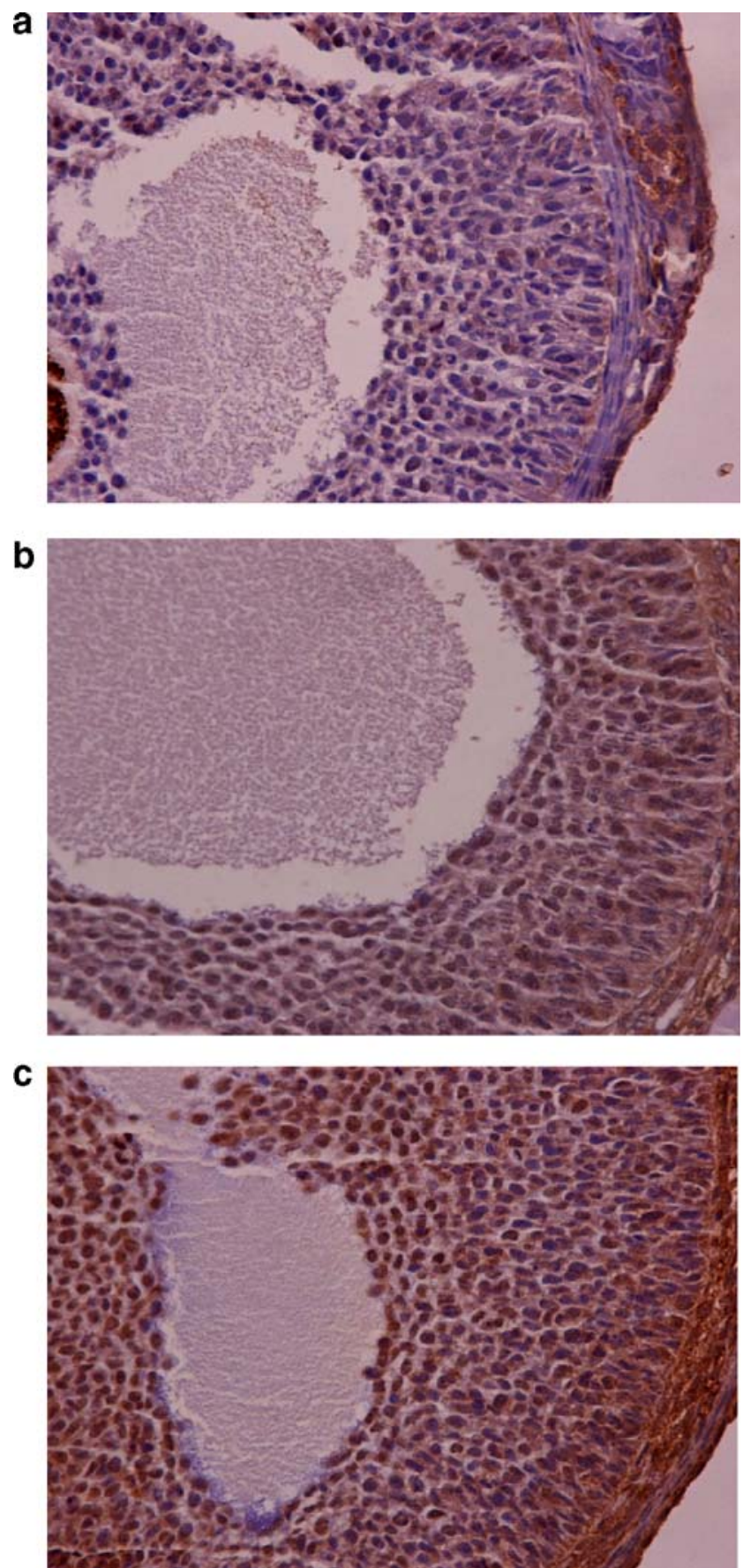

Fig. 2 Immunohistochemical localization of RAGE expression in control (a, 200× magnification), L-AGE-fed rat ovary (b, 200× magnification), and H-AGE-fed rat ovary (c, 200× magnification). RAGE immunoreactivity is observed in granulosa cells, theca interna cells, as well as endothelial and stromal cells. RAGE staining in follicular cells revealed both cytoplasmic and nuclear localization. Significant difference in RAGE staining is observed between the granulosa cell layer and theca interna of $\mathrm{H}-\mathrm{AGE}-\mathrm{fed}$ rats and controls 
Immunohistochemical localization of RAGE in ovarian tissue of control, L-AGE-fed, and H-AGE-fed rats

All but two samples (12 in 14 control/L-AGE and 19/19 HAGE cases) exhibited a significant (moderate or high) RAGE immunoreactivity, although it seemed to be higher in H-AGE tissues $(P=0.042)$. In addition, RAGE-staining intensity was also higher in H-AGE ovarian tissue $(P=0.01)$. Data are shown in Table 3.

Granulosa and theca cells displayed a cytoplasmic and nuclear RAGE immunoreactivity, whereas in luteinizing and stroma cells, RAGE staining was only cytoplasmic, in all tissue samples. RAGE expression in granulosa and theca cell layers was significantly higher in H-AGE-fed rats when compared to the control/L-AGE (logistic regression analysis, $P=0.038$ and $P=0.052$, respectively, Fig. 2). A high RAGE expression was also present in stroma and luteinizing cells, showing the same distribution in both groups (logistic regression analysis, $P=0.706$ and $P=0.481$, respectively).

RAGE staining was also observed in uterine tubes of both H-AGE and control/L-AGE ovaries, without any significant differences (logistic regression analysis, $P=0.435$ ) in the extension or the localization of immunoreactivity between the two groups.

\section{Discussion}

The present study demonstrates for the first time that normal female rats exposed to the H-AGE diet for 6 months present increased serum AGE levels as well as higher AGE and RAGE deposition in their ovarian tissue compared to L-AGEfed animals and controls. More specifically, AGE expression was stronger in the ovaries of H-AGE-fed rats compared to controls and those animals that received the L-AGE diet and in particular in the theca interna cell layer. RAGE staining was increased in both granulosa and theca interna cells of $\mathrm{H}$ AGE-fed rats compared to control/L-AGE rats.

It was also found that fasting glucose and insulin levels, as well as the weight of the ovaries, were increased in $\mathrm{H}-$ AGE-fed animals compared to the control and L-AGE, despite the fact that there was no increase in their body weight, suggesting that this impact is likely to be independent of the degree of obesity.

The present findings of AGEs deposition in the ovarian tissue in conjunction with altered metabolic profile and elevated testosterone levels provide evidence for dual effect of dietary glycotoxins, in reproductive and metabolic aspects of the female rat.

Similarities with the above findings are suggested when elevated serum AGEs with increased RAGE expression were demonstrated in women with PCOS, a female syndrome with metabolic and reproductive abnormalities [17].
Furthermore, in women with PCOS receiving a highAGE fast food meal, serum AGE levels were increased postmeal [19]. Noticeably, AGE levels were positively correlated with insulin resistance indices and hyperandrogenemia in women with PCOS $[17,19,24]$. Similarly, in the present study, in H-AGE-fed rats, testosterone levels were positively correlated with the AGE levels and ovarian weight. These findings are also in accordance with the increased distribution of AGEs and RAGE in theca cells in the same group of animals compared with the control and L-AGE-fed animals. It is known that theca cells are responsible for the androgen production in the ovarian tissue, and therefore a functional link between the increased deposition of AGE and RAGE in theca cells of H-AGE-fed animals and the increased levels of serum testosterone cannot be excluded.

The immunohistochemistry data of the study indicate that AGEs appear to be differentially distributed in the ovarian tissue. Previous observations have shown increased AGE deposition in granulosa cells from human polycystic ovarian tissue compared to controls [18], whereas in the present study, AGEs seem to localize in theca interna cells of H-AGE-fed normal female rats. It is likely that the source of AGEs, being either endogenous or exogenous, may play a role in localization of AGEs in the ovarian as well as in other tissues, as in the previous immunochemistry study of ovarian tissue, the source of these molecules could not be defined and the type of diet was not known in PCOS patients from which the ovarian tissue was obtained.

In conclusion, it is demonstrated that excess dietary glycotoxins in experimental animals appeared to be accumulated in the ovarian tissues and are also associated with metabolic and hormonal alterations. Although it is always hard to extrapolate from animal studies to humans, these findings in conjunction with human observational studies in women with PCOS provide a scientific basis for further exploration of the role of dietary glycotoxins on structural as well as functional alterations in female reproductive system.

Acknowledgments We thank Christos Adamopoulos and Stelios A. Kandarakis for technical assistance at various stages of this work.

\section{References}

1. Vlassara H, Palace MR (2002) Diabetes and advanced glycation endproducts. J Intern Med 251:87-101

2. Baynes JW (2002) The Maillard hypothesis on aging: time to focus on DNA. Ann NY Acad Sci 959:360-367

3. Vlassara H, Bucala R, Striker L (1994) Pathogenic effects of advanced glycosylation: biochemical, biologic, and clinical implications for diabetes and aging. Lab Invest 70:138-151 
4. Makino H, Shikata K, Hironaka K (1995) Ultrastructure of nonenzymatically glycated mesangial matrix in diabetic nephropathy. Kidney Int 48:517-526

5. McCance DR, Dyer DG, Dunn JA (1993) Maillard reaction products and their relation to complications in insulin-dependent diabetes mellitus. J Clin Invest 91:2470-2478

6. O'Brien J (1989) Nutritional and toxicological aspects of the Maillard browning reaction in foods. Crit Rev Food Sci Nutr 28:211-248

7. Lee T-C, Kimiagar M, Pintauro SJ, Chichester CO (1981) Physiological and safetyaspects of Maillard browning of foods. Prog Food Nutr Sci 5:243-256

8. Cai W, Cao Q, Zhu L, Peppa M, He CJ, Vlassara H (2002) Oxidative stress-inducingcarbonyl compounds from common foods: novel mediators of cellular dysfunction. Mol Med 8: 337-346

9. Goldberg T, Cai W, Peppa M, Dardaine V, Uribarri J, Vlassara H (2004) Advanced glycoxidation end products in commonly consumed foods. J Am Diet Assoc 104:1287-1291

10. Koschinsky T, He CJ, Mitsuhashi T, Bucala R, Liu C, Buenting C, Heitmann, K, Vlassara H (1997) Orally absorbed reactive glycation products (glycotoxins): an environmental risk factor in diabetic nephropathy. Proc Natl Acad Sci USA 94:6474-6479

11. Lin RY, Dore AT, Ghodsi N, Fallon JT, Fisher EA, Vlassara H (2002) Lowering of dietary advanced glycation end products (AGE) reduces neointimal formation after arterial injury in genetically hypercholesterolemic mice. Atherosclerosis 163:303-311

12. Zheng F, He C, Cai W, Hattori M, Steffes M, Vlassara H (2002) Prevention of diabetic nephropathy in mice by a diet low in glycoxidation products. Diabetes Metab Res Rev 18:224-237

13. Vlassara H, Cai W, Crandall J (2002) Inflammatory markers are induced by dietary glycotoxins: a pathway for accelerated atherosclerosis in diabetes. Proc Natl Acad Sci USA 99: 15596-15601

14. Sandu O, Song K, Cai W, Zheng F, Uribarri J, Vlassara H (2005) Insulin resistance and type 2 diabetes in high-fat-fed mice are linked to high glycotoxin intake. Diabetes 54:2314-2319
15. Hofmann SM, Dong HJ, Li Z (2002) Improved insulin sensitivity is associated with restricted intake of dietary glycoxidation products in the $\mathrm{db} / \mathrm{db}$ mouse. Diabetes 51:2082-2089

16. Uribarri J, Peppa M, Cai W (2003) Restriction of dietary glycotoxins reduces excessive advanced glycation end products in renal failure patients. J Am Soc Nephrol 14:728-731

17. Diamanti-Kandarakis E, Piperi C, Kalofoutis A, Creatsas G (2005) Increased levels of serum advanced glycation end-products in women with polycystic ovary syndrome. Clin Endocrinol (Oxf) $62: 37-43$

18. Diamanti-Kandarakis E, Piperi C, Patsouris E, Korkolopoulou P, Panidis D, Pawelczyk L, Papavassiliou AG, Duleba AJ (2007) Immunohistochemical localization of advanced glycation endproducts (AGEs) and their receptor (RAGE) in polycystic and normal ovaries. Histochem Cell Biol 127:581-589

19. Diamanti-Kandarakis E, Piperi C, Alexandraki K, Katsilambros N, Kouroupi E, Papailiou J, Lazaridis S, Koulouri E, Kandarakis HA, Douzinas EE, Creatsas G, Kalofoutis A (2006) Short-term effect of orlistat on dietary glycotoxins in healthy women and women with polycystic ovary syndrome. Metabolism 55:494-500

20. Zheng F, He C, Cai W, Hattori M, Steffes M, Vlassara H (2002) Prevention of diabetic nephropathy in mice by a diet low in glycoxidation products. Diabetes/Metab Res Rev 18:224-237

21. Lin R-Y, Reis ED, Dore AT, Lu M, Ghodsi N, Fallon JT (2002) Lowering of dietary advanced glycation endproducts (AGE) reduced neointimal formation after arterial injury in genetically hypercholesterolemic mice. Atherosclerosis 163:303-311

22. Krause R, Knoll K, Henle T (2003) Studies on the formation of furosine and pyridosine during acid hydrolysis of different Amadori products of lysine. Eur J Food Res Technol 216:277-283

23. Resmini P, Pellegrino L, Batelli G (1990) Accurate quantification of furosine in milk and dairy products by a direct HPLC method. Ital J Food Sci 3:173-183

24. Diamanti-Kandarakis E, Katsikis I, Piperi C, Alexandraki K, Panidis D (2007) Effect of long-term orlistat treatment on serum levels of advanced glycation end-products in women with polycystic ovary syndrome. Clin Endocrinol (Oxf) 66:103-109 